\title{
Kemampuan Komunikasi Matematis Siswa SMP dalam Matematika Nalaria berdasarkan Jenis Kelamin
}

\author{
Didik Sugeng Pambudi ${ }^{1}$, Risky Qurrotul Aini ${ }^{2}$, Ervin Oktavianingtyas ${ }^{3}$, \\ Dinawati Trapsilasiwi ${ }^{4}$, Saddam Hussen ${ }^{5}$ \\ 1,2,3,4,5Program Studi Pendidikan Matematika, FKIP Universitas Jember, Jember, Indonesia; \\ didikpambudi.fkip@unej.ac.id ${ }^{1 *}$
}

Info Artikel: Dikirim: 26 September 2020; Direvisi: 7 Februari 2021; Diterima: 2 Maret 2021 Cara sitasi: Pambudi, D.S., Aini, R.Q., Oktavianingtyas, E., Trapsilasiwi, D., \& Hussen, S. (2021). Kemampuan Komunikasi Matematis Siswa SMP dalam Matematika Nalaria berdasarkan Jenis Kelamin. JNPM (Jurnal Nasional Pendidikan Matematika) 5(1), 136-148.

\begin{abstract}
Abstrak. Kemampuan komunikasi matematis siswa merupakan kemampuan penting yang perlu dikuasai siswa dan menjadi salah satu standar dalam proses pembelajaran matematika di sekolah. Penelitian ini bertujuan untuk mendeskripsikan kemampuan komunikasi matematis siswa SMP dalam memecahkan masalah matematika nalaria berdasarkan jenis kelamin. Jenis penelitian yang digunakan adalah penelitian deskriptif dengan pendekatan kualitatif. Subjek penelitian adalah siswa kelas VIII SMP Negeri di Jember yang berjumlah 29 siswa, 15 laki-laki dan 14 perempuan. Data dikumpulkan menggunakan tes tertulis dan tes lisan. Triangulasi data menggunakan metode sumber, yaitu menguji kesesuaian antara data dari tes tertulis dan tes lisan. Hasil penelitian menunjukkan bahwa siswa laki-laki memiliki kemampuan komunikasi matematis yang hampir sama baiknya dengan siswa perempuan, dan termasuk dalam kategori Cukup. Perbedaannya adalah, siswa laki-laki memiliki kemampuan komunikasi tertulis lebih baik dari siswa perempuan, sedangkan siswa perempuan memiliki kemampuan komunikasi lisan lebih baik dari siswa laki-laki. Dari hasil ini direkomendasikan kepada guru matematika di sekolah untuk terus melatih siswa memecahkan masalah matematika nalaria agar kemampuan komunikasi matematis siswa dapat meningkat.
\end{abstract}

Kata Kunci: Kemampuan Komunikasi Matematis, Masalah Matematika Nalaria, Jenis Kelamin.

\begin{abstract}
Students' mathematical communication skill is an important ability that students need to master and become one of the standards in the mathematics learning process in schools. This research aimed to describe the mathematical communication skill of junior high school students in solving logical mathematical problem based on gender. This type of research is a descriptive research with a qualitative approach. The subjects of theresearch were students of class VIII SMP Negeri in Jember, totaling 29 students, 15 males and 14 females. Data is collected using written test and oral test. Data triangulation used the source method, namely testing the suitability of the data from the written test and the oral test. The results showed that male students have almost as good mathematical communication skills as female students, and are included in the Moderate category. The difference is, male students have better written communication skills than female students, while female students have better oral communication skills than male students. From these results it is recommended that mathematics teachers in schools continue to train students to solve mathematical problems so that students' mathematical communication skills can improve.
\end{abstract}

This is an open access article under the $\underline{C-B Y-S A}$ license 
Keywords: Mathematical Communication Skill, Logical Mathematical Problem, Gender.

\section{Pendahuluan}

Matematika merupakan bidang ilmu yang sangat penting bagi perkembangan Ilmu Pengetahuan dan Teknologi, sehingga dijadikan salah satu mata pelajaran wajib yang diberikan kepada siswa sejak pendidikan dasar sampai menengah (Kemdikbud, 2013). Dalam proses pembelajaran matematika siswa dituntut mampu mengungkapkan hasil pemikiran mereka dengan cara mengkomunikasikan secara lisan dan tulisan. Hal ini sesuai dengan tujuan pembelajaran matematika, yaitu agar siswa mampu mengkomunikasikan gagasan dengan simbol, tabel, diagram, atau media lain untuk memperjelas keadaan atau masalah (Kemdikbud, 2013; Pambudi, Budayasa, \& Lukito, $\underline{2020)}$.

Kemampuan Komunikasi Matematis (KKM) merupakan kemampuan yang diperlukan dalam menyampaikan pemahaman, ide, argumentasi, baik secara tulisan maupun lisan (Yilmaz \& Ozen, 2014; Kurnia, Setiawani, \& Kristiana, 2015). Lebih khusus lagi kemampuan tersebut diperlukan saat siswa memecahkan masalah matematika (Arifin, Trapsilasiwi, \& Fatahillah, 2016), seperti masalah matematika nalaria, yang berhubungan dengan kehidupan nyata (Wijaya, Imam, \&Riyadi, 2016; Rinata, \& Mariana, 2019). Dunia nyata tidak berarti konkret secara fisik dan kasat mata, namun juga termasuk yang dapat dibayangkan anak (Lippa, 2010; Putra, \& Amalia, 2019). Selain berupa soal yang realistik ciri soal dalam matematika nalaria yaitu menggunakan daya nalar dan melatih meningkatkan kemampuan berpikir tingkat tinggi dari siswa (Fuada, Sunardi, \& Setiawan, 2017).

Perbedaan jenis kelamin adalah pembeda antara laki-laki dan perempuan secara biologis sejak lahir. Laki-laki dan perempuan memiliki karakteristik alamiah yang berbeda salah satunya pada ciri-ciri kepribadian. Laki-laki terlihat lebih agresif, analitis, kompetitif, dominan, mempertahankan keyakinan, independen dan tidak emosional. Perempuan terlihat lebih mesra, lemah lembut, sensitif, emosional, bergantung dan penurut (Santrock, 2009). Beberapa hasil penelitian menunjukkan kesamaan proses perkembangan berfikir matematika dan prestasi matematika antara siswa laki-laki dan perempuan (Ajai, \& Imoko, 2015; Nugraha \& Pujiastuti, 2019; Lestari, Suesthi, \& Wiyono, 2019; Ghasemi, \& Burley, 2019; Kersey, Csumitta, \& Cantlon, 2019; Kamid, Rusdi, Fitaloka, Basuki, \& Anwar, 2020). Di pihak lain, ada peneliti yang melaporkan bahwa ada perbedaan dalam proses berpikir dan prestasi matematika, di mana siswa laki-laki umumnya lebih unggul dari siswa perempuan (Tommaso, Mendolia, \& Contini, 2016; Kwanza, Maikudi, Taiwo, 
Vintseh, Usman, Attah, \& Alaku, 2018; Pambudi, Budayasa, \& Lukito, 2018), khususnya pada keahlian visual matematis (Aini, \& Hasanah, 2019). Adapun, siswa perempuan lebih cermat dalam perhitungan dibandingkan dengan siswa laki-laki (Febriyanti \& Masriyah,_2016).

Penelitian ini bertujuan untuk mendeskripsikan bagaimana kemampuan KKM siswa laki-laki dan siswa perempuan dalam aktivitas memecahkan masalah matematika nalaria. Indikator yang digunakan adalah Indikator

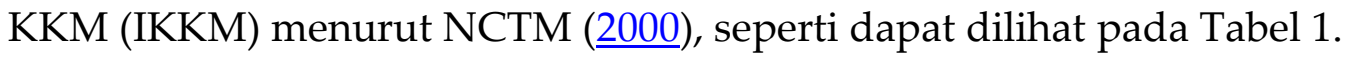

Tabel 1. Indikator Kemampuan Komunikasi Matematis (IKKM)

\begin{tabular}{|c|c|c|}
\hline \multirow[b]{2}{*}{ NCTM (2000) } & \multicolumn{2}{|c|}{ Indikator Penelitian } \\
\hline & $\begin{array}{l}\text { Kemampuan Komunikasi } \\
\text { Matematis Tulis (IKKMT) }\end{array}$ & $\begin{array}{l}\text { Kemampuan Komunikasi } \\
\text { Matematis Lisan (IKKML) }\end{array}$ \\
\hline $\begin{array}{l}\text { Kemampuan } \\
\text { mengekspresikan } \\
\text { ide-ide atau gagasan } \\
\text { matematika secara } \\
\text { tertulis maupun lisan }\end{array}$ & $\begin{array}{l}\text { 1). Menyatakan ide-ide } \\
\text { matematis dengan } \\
\text { menuliskan informasi apa } \\
\text { yang diketahui dan ditanya } \\
\text { dari suatu masalah, juga } \\
\text { menggambar sketsa atau } \\
\text { diagram. (IKKMT 1) }\end{array}$ & $\begin{array}{l}\text { 1). Menjelaskan informasi apa } \\
\text { yang diketahui dan } \\
\text { ditanya pada suatu } \\
\text { masalah, dan menjelaskan } \\
\text { gambar/diagram yang } \\
\text { dibuat. (IKKML 1) }\end{array}$ \\
\hline $\begin{array}{l}\text { Kemampuan } \\
\text { memahami, } \\
\text { menginterprestasi, } \\
\text { dan mengevaluasi }\end{array}$ & $\begin{array}{l}\text { Memahami (IKKMT 2) } \\
\text { 2). Memahami ide-ide } \\
\text { matematis untuk menyusun } \\
\text { rencana dalam memecahkan } \\
\text { masalah. }\end{array}$ & $\begin{array}{l}\text { 2). Menjelaskan ide-ide } \\
\text { matematis yang } \\
\text { berhubungan dengan } \\
\text { rencana memecahkan } \\
\text { masalah. (IKKML 2) }\end{array}$ \\
\hline $\begin{array}{l}\text { ide-ide atau gagasan } \\
\text { matematika baik } \\
\text { tertulis maupun } \\
\text { lisan. }\end{array}$ & $\begin{array}{l}\text { Menginterprestasi (IKKMT 3): } \\
\text { 3). Menginterprestasikan ide- } \\
\text { ide matematis dalam } \\
\text { melaksanakan rencana } \\
\text { memecahkan masalah. }\end{array}$ & $\begin{array}{l}\text { 3). Menjelaskan rencana/ } \\
\text { langkah-langkah yang } \\
\text { digunakan dalam meme- } \\
\text { cahkan masalah. (IKKML } \\
\text { 3) }\end{array}$ \\
\hline & $\begin{array}{l}\text { Mengevaluasi (IKKMT 4): } \\
\text { 4). Mengevaluasi jawaban } \\
\text { dengan memeriksa kembali } \\
\text { kebenaran } \\
\text { jawaban/kesimpulan. }\end{array}$ & $\begin{array}{l}\text { 4). Menjelaskan kebenaran } \\
\text { jawaban/kesimpulan yang } \\
\text { telah diperoleh. (IKKML 4) }\end{array}$ \\
\hline $\begin{array}{l}\text { Kemampuan meng- } \\
\text { gunakan simbol- } \\
\text { simbol, baik tertulis } \\
\text { maupun lisan }\end{array}$ & $\begin{array}{l}\text { 5). Menggunakan simbol- } \\
\text { simbol matematika secara } \\
\text { tulisan (IKKMT 5). }\end{array}$ & $\begin{array}{l}\text { 5). Menjelaskan simbol-simbol } \\
\text { matematika secara lisan } \\
\text { (IKKML 5). }\end{array}$ \\
\hline
\end{tabular}

Adapun kategori KKM siswa dapat dilihat pada Tabel 2. 
Tabel 2. Kategori KKM Siswa

\begin{tabular}{ccc}
\hline No. & Interval KKM $(\%)$ & Kategori KKM \\
\hline 1. & $0 \leq \mathrm{KKM}<40$ & Sangat Rendah \\
2. & $40 \leq \mathrm{KKM}<60$ & Rendah \\
3. & $60 \leq \mathrm{KKM}<70$ & Cukup/Moderat \\
4. & $70 \leq \mathrm{KKM}<80$ & Baik \\
5. & $80 \leq \mathrm{KKM} \leq 100$ & Sangat Baik \\
\hline
\end{tabular}

\section{Metode}

Jenis penelitian yang digunakan adalah penelitian deskriptif dengan pendekatan kualitatif. Penelitian dilaksanakan di SMPN 1 Jember pada bulan Januari tahun akademik 2019/2020. Subjek penelitian adalah siswa kelas VIII E yang berjumlah 29 siswa, 15 laki-laki dan 14 perempuan. Instrumen pengumpul data berupa tes tertulis, tes lisan KKM, dan rubrik penilaian. Ketiga instrumen telah divalidasi dalam hal isi dan konstruk oleh 3 validator. Hasil validasi semua instrumen tersebut dinyatakan valid dengan rata-rata koefisien validitas isi maupun konstruk terletak antara skor 2,9 sampai 3,0, skor validitas antara 0 (sangat tidak valid) sampai dengan 3,0 (sangat valid).

Untuk memperoleh data, subjek diberi tes tertulis, dan tes lisan soal matematika nalaria. Soal tersebut adalah: "Nancy memelihara kelinci sebagai hobi. Selama bulan April, jumlah kelinci meningkat 10\%. Pada bulan Mei, 10 kelinci baru lahir. Pada akhir Mei, Nancy menjual sepertiga dari kelincinya. Selama bulan Juni, 20 kelinci baru lahir. Pada akhir Juni, Nanci menjual setengah dari seluruh kelincinya. Sampai bulan Juli, 5 kelinci telah lahir sehingga Nancy memiliki 55 kelinci. Berapa kelinci yang dimiliki Nancy pada tanggal 1 April? (modifikasi dari Posamentier, \& Krulik, 1998). Setelah subjek mengerjakan soal tertulis, maka dilakukan tes lisan untuk mengetahui kemampuan subjek menjelaskan apa yang sudah dilakukan siswa saat menjawab tes tertulis. Triangulasi data dilakukan dengan menggunakan metode sumber, yaitu menguji kesesuaian antara data dari tes tertulis dan tes lisan (Moleong, 2013). Data yang sudah valid tersebut dianalisis secara deskriptif kualitatif sesuai dengan indikator dan kategori KKM yang digunakan pada Tabel 1 dan Tabel 2.

\section{Hasil dan Pembahasan}

\section{Kemampuan Komunikasi Matematis Tertulis Siswa Laki-Laki}

Contoh hasil jawaban tes tertulis dari siswa laki-laki dapat dilihat pada Gambar 1. 


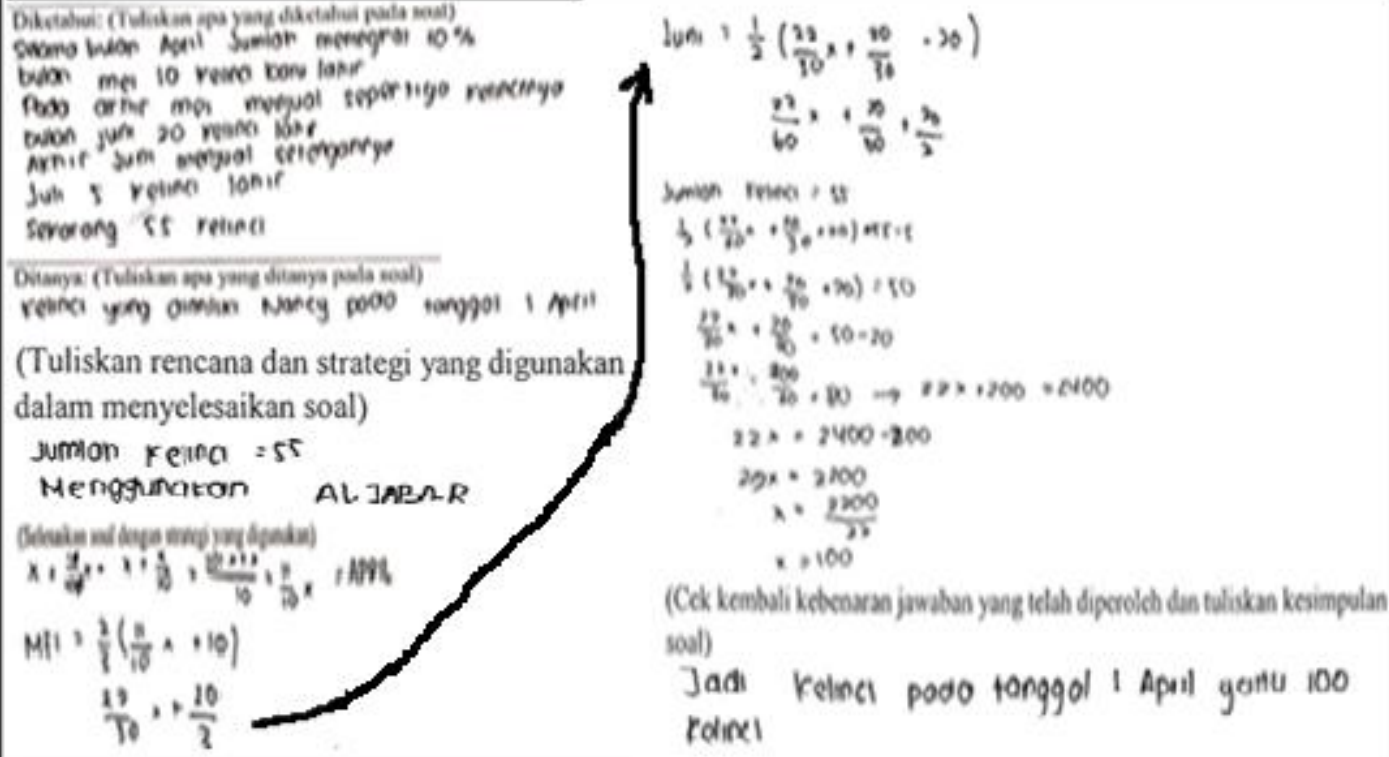

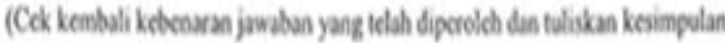
soal) Jadi Kelnat podo tonggol I Apail gattu 100 rolinel

Gambar 1. Contoh Hasil Jawaban Tes Tertulis Siswa Laki-Laki

Gambar 1 menunjukkan bahwa subjek siswa laki-laki secara umum mampu memecahkan masalah matematika nalaria dengan baik, dimulai dengan menuliskan apa yang diketahui dan ditanya. Selanjutnya, siswa menuliskan rencana, dan melaksanakan rencana. Namun, subjek siswa laki-laki tidak mampu memeriksa dan mengecek kembali kebenaran jawaban, walaupun kesimpulan yang ditulis sudah benar.

Persentase indikator kemampuan komunikasi matematis tertulis (IKKMT) yang tampak pada subjek siswa laki-laki dalam menyelesaikan masalah matematika nalaria dapat dilihat pada Gambar 2.

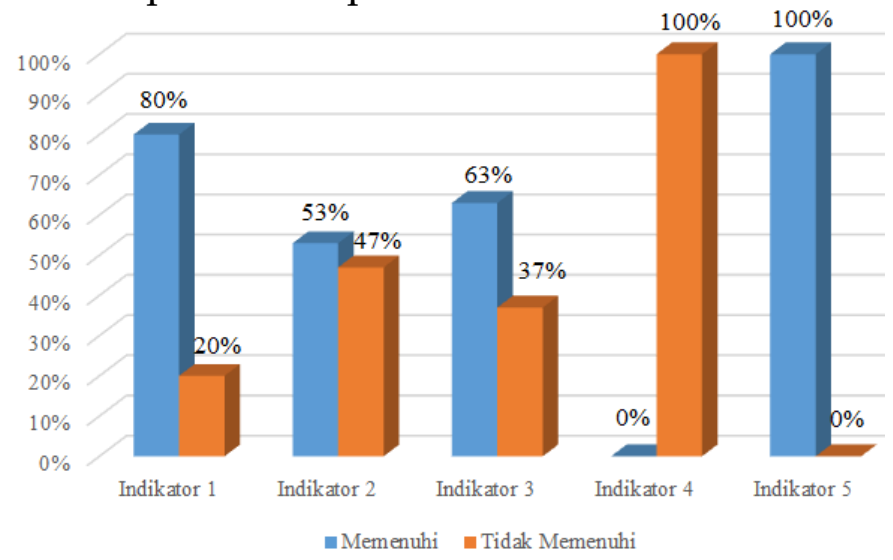

Gambar 2. Persentase IKKMT Siswa Laki-Laki

Gambar 2 menunjukkan bahwa pada IKKMT 1, ada 80\% siswa laki-laki yang mampu dalam menuliskan segala informasi pada masalah, yaitu apa yang 
diketahui dan ditanya, dengan bahasa sendiri yang lengkap dan benar. Pada IKKMT 2, ada 53\% siswa laki-laki yang mampu menuliskan rencana atau strategi pemecahan masalah yang akan digunakan dengan tepat, tetapi ada $47 \%$ yang kurang mampu. Berikutnya untuk IKKMT 3, ada 63\% siswa lakilaki yang mampu dalam menuliskan langkah-langkah yang digunakan dalam menyelesaikan masalah, dan hanya 37\% yang tidak mampu. Pada IKKMT 4, yaitu saat memeriksa kembali jawaban, semua siswa laki-laki tidak menunjukkan kemampuan memeriksa dan mengecek kembali kebenaran jawaban, walaupun kesimpulan yang ditulis sudah benar. Terakhir, pada IKKMT 5, 100\% siswa laki-laki mampu menggunakan simbol-simbol matematika dengan benar, seperti operasi matematika, variabel, dan numerik.

\section{Kemampuan Komunikasi Matematis Lisan Siswa Laki-Laki}

Dari hasil tes lisan yang diberikan kepada subjek siswa laki-laki dalam memecahkan masalah matematika nalaria, maka diperoleh persentase Indikator Kemampuan Komunikasi Matematis Lisan (IKKML) seperti disajikan pada Gambar 3.

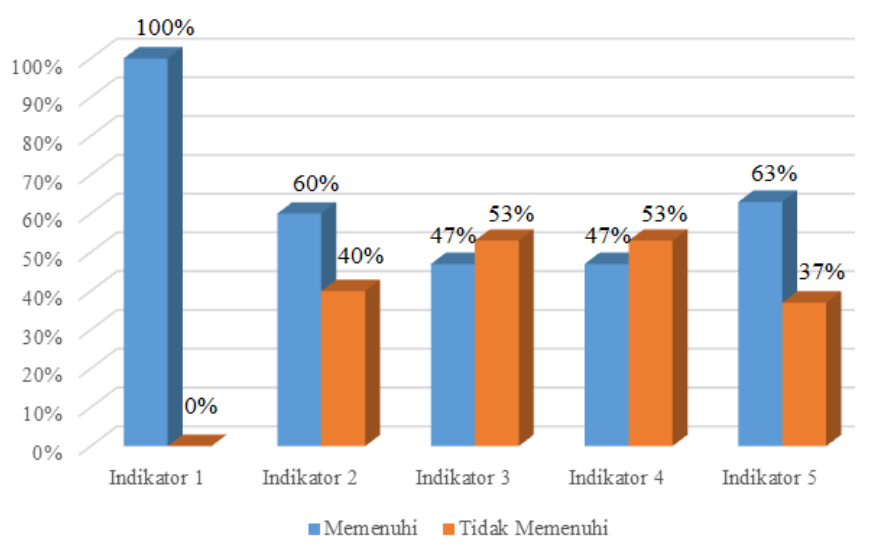

Gambar 3. Persentase IKKML Siswa Laki-Laki

Gambar 3 menunjukkan bahwa 100\% siswa laki-laki memenuhi IKKML 1, yaitu siswa mampu menjelaskan segala informasi pada masalah, yaitu apa yang diketahui dan ditanya, dengan lancar, lengkap dan benar. Pada IKKML 2, ada $60 \%$ siswa laki-laki yang mampu menjelaskan dengan lancar rencana atau strategi pemecahan masalah yang digunakan dengan tepat. Berikutnya untuk IKKML 3, ada 47\% siswa laki-laki yang mampu menjelaskan dengan lancar langkah-langkah yang sudah digunakan dalam menyelesaikan masalah, sedangkan 53\% kurang lancar menjelaskan hal tersebut. Demikian juga pada IKKML 4, ada 47\% siswa laki-laki yang mampu menjelaskan bagaimana mereka memeriksa kembali jawaban, sedangkan 53\% kurang mampu menjelaskan hal tersebut. Terakhir, pada IKKML 5, ada 63\% siswa laki-laki 
yang mampu menjelaskan pengertian simbol-simbol matematika yang digunakan dengan lancar dan benar, seperti operasi matematika, variabel, dan numerik.

\section{Kemampuan Komunikasi Matematis Tertulis Siswa Perempuan}

Contoh hasil jawaban tes tertulis dari siswa perempuan dapat dilihat pada Gambar 4.

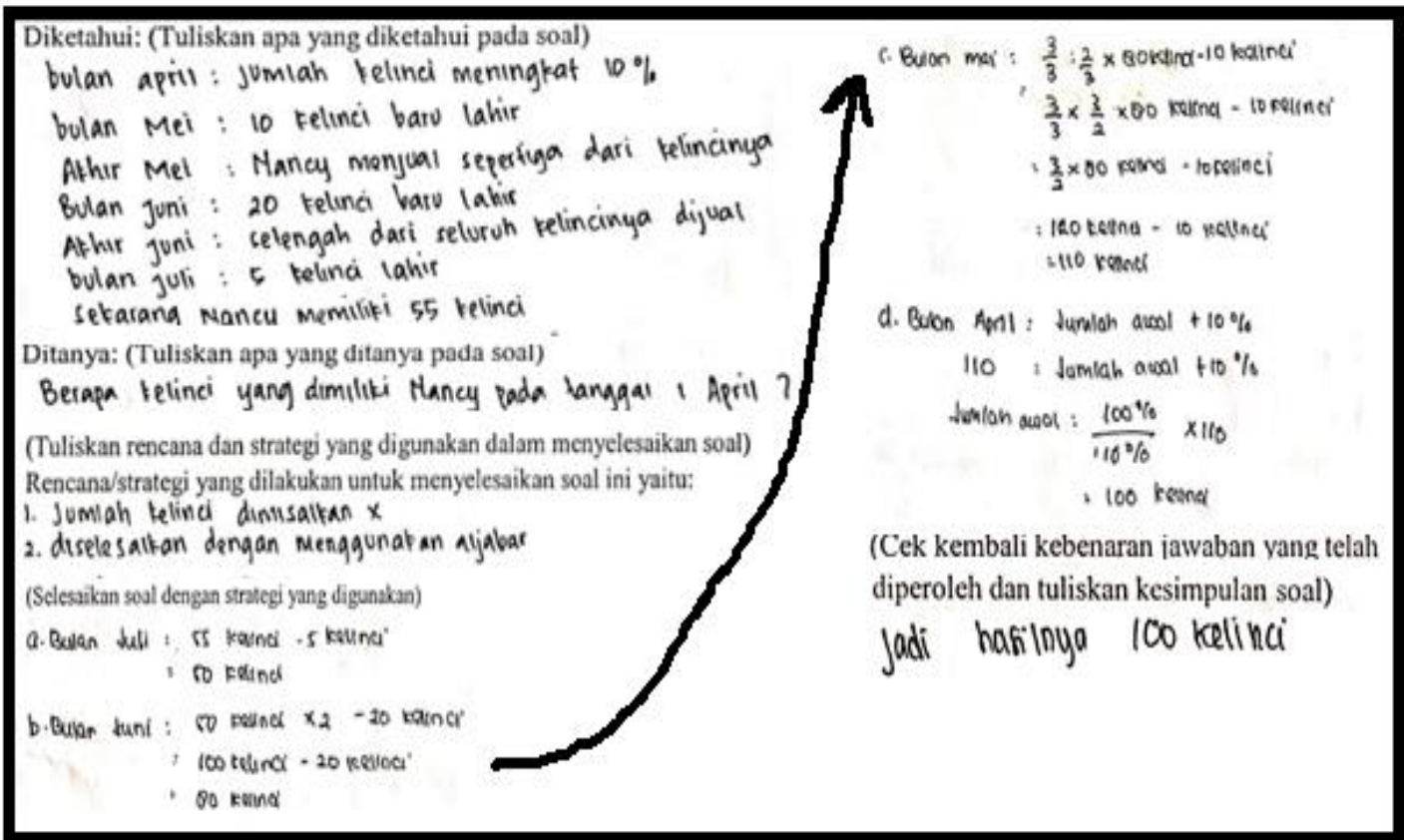

Gambar 4. Contoh Hasil Jawaban Tes Tertulis Siswa Perempuan

Gambar 4 menunjukkan bahwa subjek siswa perempuan secara umum mampu memecahkan masalah matematika nalaria dengan baik, dimulai dengan menuliskan apa yang diketahui dan ditanya dengan jelas. Selanjutnya, siswa menuliskan rencana, memisalkan variabel x sebagai jumlah kelinci. Berikutnya, siswa melaksanakan rencana dengan menggunakan rumus dan operasi matematika yang benar. Namun, subjek siswa perempuan tidak mampu memeriksa dan mengecek kembali kebenaran jawaban, melainkan hanya menuliskan kesimpulan.

Persentase indikator kemampuan komunikasi matematis tertulis (IKKMT) yang tampak pada subjek siswa perempuan dalam menyelesaikan masalah matematika nalaria dapat dilihat pada Gambar 5 . 


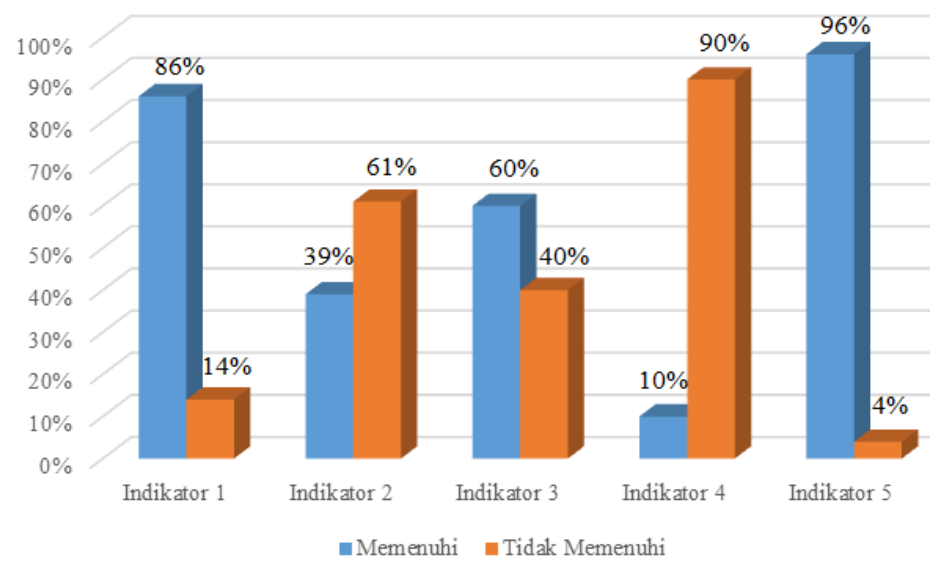

Gambar 5. Persentase IKKMTSiswa Perempuan

Gambar 5 menunjukkan bahwa pada IKKMT 1, ada 86\% siswa perempuan yang mampu dalam menuliskan segala informasi pada masalah, yaitu apa yang diketahui dan ditanya, dengan bahasa sendiri yang lengkap dan benar. Pada IKKMT 2, hanya 39\% siswa perempuan yang mampu menuliskan rencana atau strategi pemecahan masalah yang akan digunakan dengan tepat, sedangkan 61\% kurang mampu. Berikutnya untuk IKKMT 3, ada 60\% siswa perempuan yang mampu menuliskan langkah-langkah yang digunakan dalam menyelesaikan masalah dengan jelas dan benar, dan ada $40 \%$ yang tidak mampu. Pada IKKMT 4, ternyata hanya 10\% siswa perempuan yang memeriksa kembali jawabannya, sedangkan 90\% tidak melakukan pengecekan tersebut. Terakhir, pada IKKMT 5, 96\% siswa perempuan mampu menggunakan simbol-simbol matematika dengan benar, seperti operasi matematika, variabel, dan numerik.

\section{Kemampuan Komunikasi Matematis Lisan Siswa Perempuan}

Dari hasil tes lisan yang diberikan kepada subjek siswa perempuan dalam memecahkan masalah matematika nalaria, maka diperoleh persentase Indikator Kemampuan Komunikasi Matematis Lisan (IKKML) siswa perempuan dalam menyelesaikan masalah matematika nalaria, seperti dapat dilihat pada Gambar 6. 


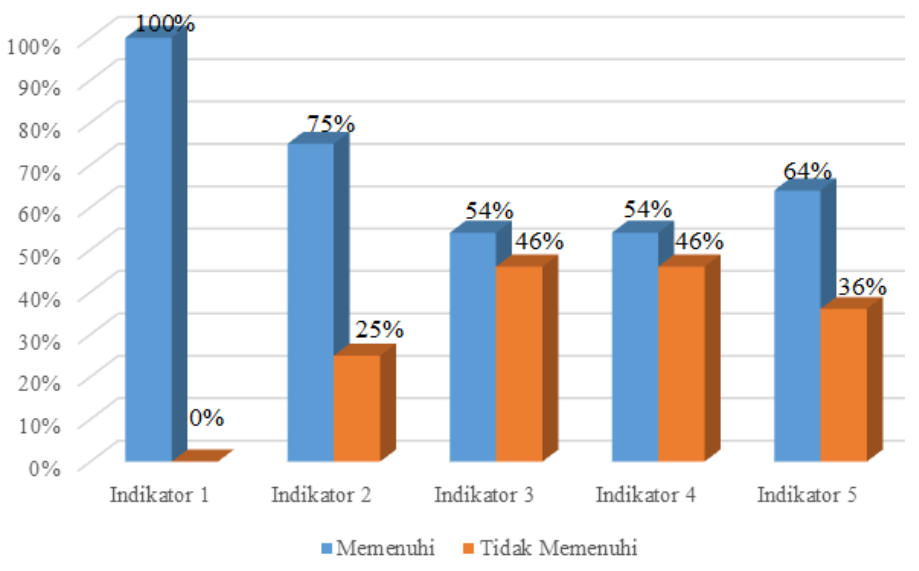

Gambar 6. Persentase IKKMLSiswa Perempuan

Gambar 6 menunjukkan bahwa 100\% siswa perempuan memenuhi IKKML 1, yaitu siswa mampu menjelaskan segala informasi pada masalah, yaitu apa yang diketahui dan ditanya, dengan lancar, lengkap dan benar. Pada IKKML 2 , ada $75 \%$ siswa perempuan yang mampu menjelaskan dengan lancar rencana atau strategi pemecahan masalah yang digunakan dengan tepat. Berikutnya untuk IKKML 3, ada 54\% siswa perempuan yang mampu menjelaskan dengan lancar langkah-langkah yang sudah digunakan dalam menyelesaikan masalah, sedangkan 46\% kurang lancar menjelaskan hal tersebut. Demikian juga pada IKKML 4, ada 54\% siswa perempuan yang mampu menjelaskan bagaimana mereka memeriksa kembali jawaban, sedangkan $46 \%$ kurang mampu menjelaskan hal tersebut. Terakhir, pada IKKML 5, baru 64\% siswa perempuan yang mampu menjelaskan pengertian simbol-simbol matematika yang digunakan dengan lancar dan benar, seperti operasi matematika, variabel, dan numerik; sedangkan $36 \%$ kurang mampu menjelaskan hal tersebut dengan benar.

Dari hasil di atas, maka dapat dibandingkan kemampuan komunikasi matematis, antara siswa laki-laki dengan siswa perempuan dalam memecahkan masalah matematika nalaria, seperti tampak pada Tabel 3.

Tabel 3. Perbandingan Persentase IKKM yang Dipenuhi Siswa

\begin{tabular}{|c|c|c|c|c|c|c|c|c|c|c|c|c|c|}
\hline \multirow{2}{*}{ Gender } & \multicolumn{10}{|c|}{ IKKM (\%) } & \multicolumn{3}{|c|}{ Rerata (\%) } \\
\hline & $\mathrm{T} 1$ & L1 & $\mathrm{T} 2$ & $\mathrm{~L} 2$ & $\mathrm{~T} 3$ & L3 & $\mathrm{T} 4$ & $\mathrm{~L} 4$ & T5 & L5 & $\mathrm{T}$ & $\mathrm{L}$ & KKM \\
\hline Laki-laki & 80 & 100 & 53 & 60 & 63 & 47 & 0 & 47 & 100 & 63 & 59,2 & 63,4 & 61,3 \\
\hline Perempuan & 86 & 100 & 39 & 75 & 60 & 54 & 10 & 54 & 96 & 64 & 58,2 & 69,4 & 63,8 \\
\hline
\end{tabular}

Catatan: T1 =IKKMT 1, L1 = IKKML 1, dan seterusnya sampai T5 =IKKMT 5, L5 = IKKML 5

$\mathrm{T}=(\mathrm{T} 1+\mathrm{T} 2+\mathrm{T} 3+\mathrm{T} 4+\mathrm{T} 5) / 5, \quad \mathrm{~L}=(\mathrm{L} 1+\mathrm{L} 2+\mathrm{L} 3+\mathrm{L} 4+\mathrm{L} 5) / 5, \quad \mathrm{KKM}=(\mathrm{T}+\mathrm{L}) / 2$

Tabel 3 menunjukkan bahwa pada IKKMT 1, siswa perempuan (86\%) memiliki kemampuan lebih baik daripada siswa laki-laki (80\%), tetapi pada 
IKKML 1, siswa laki-laki (100\%) sama baiknya dengan siswa perempuan (100\%). Jadi, siswa perempuan memiliki kemampuan tertulis lebih baik daripada siswa laki-laki dalam menuliskan informasi yang diketahui dan ditanya dari masalah matematika nalaria.

Pada IKKMT 2, siswa laki-laki (53\%) memiliki kemampuan lebih baik daripada siswa perempuan (39\%), tetapi pada IKKML 2, siswa perempuan (75\%) memiliki kemampuan lebih baik daripada siswa laki-laki (60\%). Jadi, siswa laki-laki memiliki kemampuan lebih baik daripada siswa perempuan dalam menuliskan rencana atau strategi pemecahan masalah yang digunakan saat menjawab tes tertulis, tetapi siswa perempuan memiliki kemampuan lebih baik daripada siswa laki-laki dalam menjelaskan secara lisan, rencana atau strategi pemecahan masalah yang digunakan.

Pada IKKMT 3, siswa laki-laki (63\%) memiliki kemampuan lebih baik dari siswa perempuan (60\%), tetapi untuk IKKML 3, siswa perempuan (54\%) memiliki kemampuan lebih baik daripada siswa laki-laki (47\%). Jadi, siswa laki-laki memiliki kemampuan lebih baik daripada siswa perempuan dalam menuliskan langkah-langkah pemecahan masalah saat menjawab tes tertulis, tetapi siswa perempuan memiliki kemampuan lebih baik daripada siswa lakilaki dalam menjelaskan secara lisan, langkah-langkah pemecahan masalah yang digunakan.

Pada IKKMT 4, siswa perempuan (10\%) memiliki kemampuan lebih baik daripada siswa laki-laki (0\%), dan pada IKKML 4, siswa perempuan (54\%) memiliki kemampuan lebih baik daripada siswa laki-laki (47\%). Jadi, siswa perempuan memiliki kemampuan lebih baik dari pada siswa laki-laki dalam memeriksa kembali jawaban, baik secara tertulis maupun lisan.

Terakhir, pada IKKMT 5, siswa laki-laki (100\%) memiliki kemampuan lebih baik dari siswa perempuan (96\%), tetapi pada IKKML 5, siswa perempuan (64\%) memiliki kemampuan lebih baik dari siswa laki-laki (63\%). Jadi, siswa laki-laki memiliki kemampuan yang lebih baik dari siswa perempuan dalam menuliskan simbol-simbol matematika yang digunakan pada saat tes tertulis, sedangkan siswa perempuan memiliki kemampuan yang lebih baik dari siswa laki-laki dalam menjelaskan secara lisan, pengertian simbol-simbol matematika yang digunakan dengan lancar dan benar.

Dari rata-rata persentase IKKMT, tampak bahwa siswa laki-laki $(59,2 \%)$ memiliki kemampuan komunikasi tertulis lebih baik dari siswa perempuan $(58,2 \%)$. Dipihak lain, dari rata-rata persentase IKKML, tampak bahwa siswa 
perempuan $(69,4 \%)$ memiliki kemampuan komunikasi lisan lebih baik dari siswa laki-laki (63,4\%). Adapun secara umum, siswa perempuan (63,8\%) memiliki Kemampuan Komunikasi Matematis (KKM) yang sama baiknya dengan siswa laki-laki (61,3\%), yaitu masuk dalam kategori Cukup.

Hasil tersebut sesuai dengan teori yang menyatakan bahwa perempuan lebih mampu mengemukakan sesuatu secara lisan, serta lebih memperhatikan ketelitian, dan kecermatan (Santrock, 2009; Febriyanti \& Masriyah, 2016).Hasil penelitian ini juga sesuai dengan hasil penelitian yang dilaporkan oleh Ajai, \&

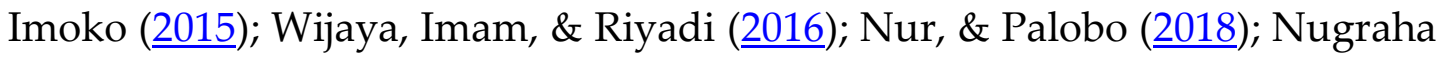
\& Pujiastuti (2019); Lestari, Suesthi, \&Wiyono (2019), Ghasemi, \& Burley (2019); Kamid, Rusdi, Fitaloka, Basuki, \& Anwar (2020), dimana, siswa lakilaki dan siswa perempuan memiliki kemampuan yang hampir sama baiknya dalam memahami masalah, menyusun rencana, melaksanakan langkahlangkah, menggunakan simbol, dan memeriksa kembali jawaban.

\section{Simpulan}

Disimpulkan bahwa siswa laki-laki memiliki kemampuan komunikasi matematis yang hampir sama baiknya dengan siswa perempuan dalam aktivitas memecahkan masalah matematika nalaria. Perbedaannya adalah, siswa laki-laki memiliki kemampuan komunikasi tertulis lebih baik dari siswa perempuan, sedangkan siswa perempuan memiliki kemampuan komunikasi lisan lebih baik dari siswa laki-laki. Kemampuan komunikasi matematis siswa SMP dalam memecahkan masalah matematika nalaria termasuk dalam kategori Cukup. Dari hasil ini direkomendasikan kepada guru matematika di sekolah untuk terus melatih siswa memecahkan masalah matematika nalaria agar kemampuan komunikasi matematis siswa dapat meningkat.

\section{Daftar Pustaka}

Aini, S.D., \& Hasanah, S.I. (2019). Berfikir Visual dan Memecahkan Masalah: Apakah Berbeda Berdasarkan Gender?. Jurnal Nasional Pendidikan Matematika. 3(2), 177-190.

Ajai, J.T., \& Imoko, B.I. (2015). Gender Differences in Mathematics Achievement and Retention Scores: A Case of Problem-Based Learning Method. International Journal of Research in Education and Sciences. 1(1), 44-50.

Arifin, Z., Trapsilasiwi, D., \& Fatahillah, A. (2016). Analisis Kemampuan Komunikasi Matematika Dalam Menyelesaikan Masalah Pada Pokok Bahasan Sistem Persamaan Linier Dua Variabel Siswa Kelas VIII-C SMP Nuris Jember (An Analysis of Mathemathic Communication Skill in Solving Problems Linear Equation System of Two Variables Students Class VIII-C SMP Nuris Jember). Jurnal Edukasi Unej. 3(2), 9-12.

Febriyanti, R., \& Masriyah. (2016). Profil Pemecahan Masalah Matematika Siswa dalam Menyelesaikan Soal Cerita Ditinjau dari Perbedaan Jenis Kelamin. MATHEdunesa. 2(5), 81-89. 
Fuada, M. S., Sunardi, \& Setiawan, T. B. (2017). Analisis Kemampuan Penalaran dan Komunikasi Matematis dalam Menyelesaikan Soal Pemecahan Masalah Matematika pada Siswa Kelas VII SMPN 2 Jember (The Analysis Of Mathematical Reasoning and Communication Ability In Solving Math Problems On The Seventh Grade. Kadikma. 8(2), 114-124.

Ghasemi, E., \& Burley, H. (2019). Gender, Affect, and Math: a Cross National Meta-Analysis of Trends in International Mathematics and Science Study 2015 Outcomes. Large Scale Assessments in Education. 7(10), 1-25.

Kamid, Rusdi, M., Fitaloka, O., Basuki, F. R., \& Anwar, K. (2020). Mathematical Communication Skills based on Cognitif Styles and Gender. International Journal of Evaluation and Research in Education, 9(4), 847-856.

Kemdikbud. (2013). Kurikulum 2013. Kemdikbud: Jakarta.

Kersey, A. J., Csumitta, K. D., \& Cantlon, J. F. (2019). Gender Similarities in the Brain during Mathematics Development. Nature Patrner Journals. 19(4), 1-7.

Kurnia, R. N., Setiawani, S., \& Kristiana, A. I. (2015). Analisis Kemampuan Komunikasi Matematis Siswa Kelas VII C SMP Negeri 1 Rogojampi Tahun Pelajaran 2014 / 2015 (Analysis Of Student Mathematical Communication Ability At 7 st Grade C of SMP Negeri 1 Rogojampi School Year 2014 / 2015). Artikel Ilmiah Remaja, 1(1), 1-6.

Kwanza, A., Maikudi, Taiwo, A.M., Vintseh, Usman, I.M., Attah, A.E., \& Alaku, M.E. (2018). Assessment of Gender and Interest in Mathematics Achievement in Keffe Lokal Goverment Area of Nasarawa State, Nigeria. International Journal of Operational Research in Management, Social sciences and Education, 4(1), 127-140.

Lestari, R., Suesthi, D.,\& Wiyono, H.J. (2019). Profil Kemampuan Komunikasi Matematis Tertulis Siswa MA dalam MemecahkanMasalah Permutasi Ditinjau dari Perbedaan Gender. Majamath, 2(1), 56-63.

Lippa, R. A. (2010). Gender Differences in Personality and Interests: When, Where, and Why. Chalifornia: Blackwell Publishing.

Moleong, L. J. (2013). Metodologi penelitian kualitatif. Bandung: Remaja Rosdakarya.

National Council of Teachers of Mathematics. (2000). Principles and standards for school mathematics. Reston, VA: NCTM.

Nugraha, T.H., \& Pujiastuti, H. (2019). Analisis Kemampuan Komunikasi Matematis Siswa Berdasarkan Perbedaan Gender. Edumatica, 9(1), 1-7.

Nur, A. S., \& Palobo, M. (2018). Profil Kemampuan Pemecahan Masalah Matematika Siswa Ditinjau dari Perbedaan Gaya Kognitif dan Gender. Jurnal Matematika Kreatif-Inofatif, 9(2), 139-148.

Pambudi, D. S., Budayasa, I. K., \& Lukito, A. (2018). Mathematical Connection Profile of Junior High School Students in Solving Mathematical Problems based on Gender Difference. International Journal of Scientific Research and Management (IJSRM), 6(8), 73-78.

Pambudi, D. S., Budayasa, I. K., \& Lukito, A. (2020). The Role of Mathematical Connections in Mathematical Problem Solving. Jurnal Pendidikan Matematika, 14(2), 129-144.

Posamentier, A. S., \& Krulik, S. (1998). Problem-Solving Strategies For Efficient And Elegant Solutions: A resource for the Mathematics Teacher. California: Corwin Press, Inc.

Putra, E. D., \& Amalia, R. (2019). Deskripsi Kemampuan Komunikasi Matematis Siswa dalam Pembelajaran Matematika Nalaria Realistik. Jurnal Dimensi Pendidikan dan Pembelajaran. 7(2), 61-73.

Rinata, M. V., \& Mariana. N. (2019). Penerapan Metode Matematika Nalaria Realistik di Klinik Pendidikan MIPA Cabang 1 Surabaya. Jurnal Penelitian Pendidikan Guru Sekolah Dasar, 7(1), 2525-2538. 
Santrock, J. W.(2009).Psikologi pendidikan. Educational psychology. (3 ${ }^{\text {rd }}$ ed.), Jakarta: Salemba.

Tommaso, M.L., Mendolia, S., \& Contini, D. (2016). The Gender Gap in Mathematic Achievement: Evidence from Italian Data. IZA Discussion Paper No. 10053, July 2016, 123.

Wijaya, H.P., Imam, \&Riyadi, S. (2016). Kemampuan Komunikasi Matematis Siswa Sesuai dengan Gender dalam Pemecahan Masalah Pada Materi Balok dan Kubus (Studi Kasus Pada Siswa SMP Kelas VIII Islam Al-Azhar 29 Semarang). Jurnal Elektronik Pembelajaran Matematika, 4(9), 778.

Yilmaz, Z., \& Ozen, Z. (2014). Connecting mathematical reasoning and language arts skills: The case of common core state standards. Procedia - Social and Behavioral Sciences, 116, 3716-3721. 